\title{
MAKNA ALASAN-ALASAN TERTENTU DALAM KODE ETIK NOTARIS TERKAIT KEWAJIBAN MENJALANKAN JABATAN NOTARIS DI KANTORNYA
}

\author{
Ajeng Fitrah Ramadhan, Iwan Permadi \\ Program Studi Magister Kenotariatan \\ Fakultas Hukum Universitas Brawijaya \\ Email : ajengfitrah40@gmail.com (082230308225)
}

\begin{abstract}
: this paper aims to analyze the meaning of "certain reasons" in Article 3 Paragraph 15 of the Notary Ethics Code about the obligation to carry out his position in the office and the consequences of violating these provisions against the authenticity of the deed. This study uses the normative juridical method with the statute approach and conceptual approach. The results of the study indicate that the meaning of "certain reasons" referred to Article 3 Paragraph 15 of the Notary Ethics Code is the reasons permitted by the Law, namely related to the making of a deed that is not possible to be carried out in a notary's office. The deed is authentic if in making it does not violate one of the terms of authenticity of the notary deed even though the notary violates the provisions of Article 3 Paragraph 15.
\end{abstract}

Key words: certain reasons, ethics code, obligation, public notary

\begin{abstract}
Abstrak: Tulisan ini bertujuan menganalisis makna "alasan-alasan tertentu" dalam Pasal 3 ayat 15. Kode Etik Notaris, terkait kewajiban untuk menjalankan jabatan di kantornya dan konsekuensi pelanggaran ketentuan tersebut terhadap otentisitas akta. Metode yang digunakan adalah metode yuridis normatif dengan pendekatan peraturan perundang-undangan dan pendekatan konseptual. Hasil kajian menunjukan bahwa makna "alasan-alasan tertentu" yang dimaksud dalam Pasal 3 angka 15 Kode Etik Notaris adalah alasanalasan yang diperbolehkan oleh Undang-Undang, yakni terkait pembuatan akta relaas yang tidak dimungkinkan dilaksanakan di kantor notaris. Apabila notaris melakukan pelanggaran terhadap ketentuan Pasal 3 Angka 15 dalam pembuatan akta otentik, namun dalam pembuatannya tidak melanggar salah satu ataupun beberapa bahkan semua syarat otentisitas akta, maka akta tersebut tetap merupakan suatu akta otentik.
\end{abstract}

Kata kunci: alasan-alasan tertentu, kode etik, kewajiban, menjalankan jabatan.

\section{PENDAHULUAN}

Seorang notaris dalam menjalankan tugas jabatannya haruslah berpegang teguh pada ketentuan Undang-Undang Jabatan (UUJN). Notaris juga harus berpegang teguh pada ketentuan yang diatur dalam kode etik jabatan, tanpa adanya aturan tentang kode etik, tidak adanya profesionalitas dan hilangnya kepercayaan masyarakat maka harkat dan martabat seorang notaris akan dipertaruhkan.

Nilai moral yang tinggi diperlukan oleh seorang notaris sebagai kontrol terhadap dirinya dan meminimalisir kemungkinan adanya penyalahgunaan wewenang, sehingga dapat menjaga martabatnya sebagai pejabat umum yang mempunyai tugas untuk memberikan suatu pelayanan sesuai aturan yang telah berlaku. Kode etik notaris ditetapkan oleh Ikatan Notaris Indonesia (INI) satu-satunya organisasi profesi notaris di Indonesia yang telah berbadan hukum yang pengesahannya dilakukan oleh Menteri Hukum dan HAM. Hal ini sesuai dengan Pasal 82 Ayat (1) UUJN yang menyebutkan notaris berhimpun dalam satu wadah organisasi notaris. 
Hubungan profesi notaris dengan organisasi diatur dalam kode etik notaris (KEN). KEN memuat unsur kewajiban, larangan, pengecualian dan sanksi yang akan dijatuhkan apabila notaris melakukan pelanggaran terhadap kode etik. Selain itu kode etik juga mengatur tata cara penegakkan kode etik dan pemecatan sementara sebagai anggota INI (Ikatan Notaris Indonesia, 2008: 194).

Kode Etik dalam hal ini mempunyai kekuatan mengikat bagi seluruh notaris karena terdapat pendelegasian wewenang oleh Undang-Undang kepada INI untuk dapat menetapkan kaidah-kaidah yang ditampung dalam suatu aturan kode etik yang kemudian berlaku bagi seluruh notaris yang ada di Indonesia. Ketentuan Pasal 1 angka 2 Kode Etik Notaris merupakan kaidah moral yang ditentukan berdasarkan keputusan Kongres INI dan/atau yang ditentukan dan diatur dalam suatu peraturan perundang-undangan. Oleh karena itu berlaku dan wajib untuk diaati oleh setiap dan semua anggota INI serta semua orang yang melaksanakan tugas jabatan sebagai notaris, termasuk pula para pejabat sementara notaris, dan notaris pengganti pada saat pelaksanaan jabatannya.

Kode Etik Notaris mengatur beberapa hal terkait dengan jabatan notaris seperti kewajiban, larangan, pengecualian, sanksi dan ketentuan-ketentuan lainnya terkait dengan pelaksanan jabatan notaris. Kewajiban dalam melaksanakan jabatannya terdapat dalam Pasal 3 KEN, salah satu kewajiban menurut Pasal 3 Angka $15 \mathrm{KEN}$ adalah notaris wajib untuk menjalankan jabatan notaris di kantornya, kecuali alasan-alasan tertentu. Berdasarkan bunyi pasal tersebut terdapat frasa yang tidak jelas atau kabur yaitu frasa yang menyatakan "alasan-alasan tertentu”. Dalam ketentuan KEN ataupun ketentuan lainnya tidak dijelaskan lebih lanjut apakah yang tergolong ke dalam alasan-alasan tertentu tersebut sehingga memunculkan celah bagi notaris dengan seringnya membuat akta di luar kantornya.
Hal ini merupakan konsekuensi atas ketidakjelasan makna dari frasa tersebut, maka perlu diketahui secara jelas makna sebenarnya dari "alasan-alasan tertentu" oleh pembentuk aturan. Karena hal ini berkaitan dengan penjatuhan sanksi terhadap pelanggaran ketentuan Pasal tersebut. Dengan jelasnya makna dari alasan-alasan tertentu maka Notaris dapat mengetahui apa sebenarnya yang tidak termasuk pada pengecualian dalam pasal tersebut, sehingga mengetahui batasan-batasannya, dan tidak terjadi suatu pelanggaran terkait dengan hal tersebut .

Selanjutnya bila dikaitkan dengan ketentuan dalam UUJN yang merupakan dasar hukum utama Notaris dalam menjalankan jabatannya juga terdapat beberapa larangan, yang salah satunya adalah terkait dengan larangan Notaris untuk menjalankan atau melaksanakan jabatannya di luar wilayah jabatannya yaitu dalam Pasal 17 ayat (1) UUJN. Berdasarkan ketentuan Pasal tersebut maka dapat diketahui bahwa secara argumentum a contrario atau penafsiran terbalik dapat dipahami bahwa seorang Notaris diperbolehkan untuk menjalankan kewenangan berdasarkan jabatan yang dimilikinya terkait dengan pembuatan akta sepanjang hal tersebut dilakukan dalam wilayah jabatannya. Notaris dalam hal ini mempunyai wilayah jabatan yang mencakup seluruh wilayah provinsi dari tempat kedudukan Notaris itu sendiri, hal ini di atur dalam ketentuan Pasal 18 ayat (2) UUJN yang menyatakan bahwa Notaris mempunyai wilayah jabatan yaitu mencakup semua wilayah provinsi dari tempat kedudukan Notaris tersebut. Kemudian yang dimaksud dengan tempat kedudukan adalah di daerah kabupaten atau kota.

Lebih lanjut dalam ketentuan Pasal 19 ayat (3) UUJN menentukan bahwa Notaris tidak berwenang berturut-turut tetap menjalakan jabatan di luar tempat kedudukannya. Berdasarkan ketentuan tersebut diatas maka dapat diketahui bahwa Notaris diperbolehkan untuk menjalankan 
jabatannya tidak hanya di luar kantornya saja tetapi juga diperbolehkan di luar tempat kedudukan sebagai Notaris dengan syarat tidak dilaksankaan secara terus menerus dan masih berada dalam wilayah jabatannya. Berdasarkan hal tersebut berarti bahwa Notaris diperbolehkan untuk menjalankan jabatannya di luar kantornya, namun dalam hal ini tentu juga dapat menjadi celah bagi Notaris untuk menjalakan jabatannya di luar kantornya secara terus menerus karena adanya ketidakjelasan makna dari frasa "alasanalasan tertentu" dalam ketentuan KEN, selain itu hal ini juga karena dalam ketentuan UUJN tidak secara tegas mengklasifikasikan pelaksanaan jabatan di luar kantor sebagai larangan, namun UUJN hanya menentukan bahwa Notaris tidak berwenang menjalankan jabatan sebagai Notaris di luar tempat kedudukan sebagai Notaris secara berturutturut dengan tetap, dan tidak diatur tentang sanksi terkait dengan pelanggaran Pasal tersebut. Permasalahan lain yang timbul terkait hal ini adalah terkait otentisitas akta yang dibuat oleh Notaris diluar kantor tanpa adanya alasan-alasan tertentu seperti yang disebutkan dalam KEN tersebut. Apakah berpengaruh terhadap otentisitas dari akta tersebut atau tidak dengan adanya pelanggaran ketentuan tersebut.

Seorang notaris harus dapat memberi jaminan kepastian hukum kepada masyarakat sebagai pengguna jasa. Kepastian hukum dalam hal ini berarti adanya pemberlakuan hukum yang mengatur secara tetap, jelas, konsisten dan konsekuen, yang mengandung arti bahwa pelaksanaanya tidak dapat dipengaruhi keadaan-keadaan yang bersifat subjektif. Kepastian hukum ini penting adanya karena hukum tanpa nilai kepastian akan kehilangan makna sehingga tidak dapat digunakan sebagai pedoman perilaku bagi masyarakat (Yoga, 2018). Oleh karena itu dalam hal ini tentu perlu adanya kejelasan terkait dengan norma yang diatur dalam UUJN dan KEN terutama kaitannya dengan pelaksanaan jabatan notaris itu sendiri, karena seperti kita ketahui antara UUJN dan KEN harus mempunyai keterkaitan sehingga tidak menimbulkan inkonsistensi maupun kekaburan norma makna dalam kedua aturan tersebut.

Berdasarkan latar belakang di atas, penelitian ini bertujuan untuk menganalisis dan mendeskripsikan makna dari alasanalasan tertentu yang dimaksud dalam ketentuan Pasal 3 angka 15 KEN dan untuk menganalisis dan mendeskripsikan terkait dengan pelanggaran ketentuan Pasal 3 angka 15 KEN terhadap otentisitas akta yang dibuat oleh notaris.

\section{METODE}

Metode kajian dalam artikel ini menggunakan metode yuridis normatif dengan pendekatan perundang-undangan dan pendekatan konseptual. Bahan hukum primer yang digunakan berupa Undangundang Dasar Negara Republik Indonesia Tahun 1945, Kitab Undang-Undang Hukum Perdata, Undang-Undang Nomor 30 Tahun 2004 tentang Jabatan Notaris, Undang-Undang Nomor 2 Tahun 2014 tentang Perubahan Atas Undang-Undang Nomor 30 Tahun 2004 tentang Jabatan Notaris, Kongres Luar Biasa Ikatan Notaris Indonesia Bandung 28 Januari 2005, Perubahan Kode Etik Notaris Kongres Luar Biasa INI Banten, 29-30 Mei 2015. Data sekunder berupa literatur-literatur, hasil-hasil penelitian, makalah-makalah dalam seminar, artikelartikel yang berkaitan dengan isu hukum yang diangkat dalam jurnal ini. Data tersier yang digunakan berupa sumber-sumber dari internet. Kajian ini termasuk library research atau studi kepustakaan yang memiliki keterkaitan dengan objek kajian permasalahan yang akan dibahas. Interpretasi yang dipergunakan dalam penelitian ini adalah interpretasi gramatikal, teleologis atau sosiologis dan interpretasi argumentum contrario.

\section{HASIL DAN PEMBAHASAN}

Makna "Alasan-Alasan Tertentu" dalam Pasal 3 Angka 15 Kode Etik Notaris terkait 
Kewajiban Notaris untuk Menjalankan Jabatan di Kantornya

Notaris harus berpegang teguh pada kode etik profesi. Kode Etik profesi merupakan produk etika terapan, karena dihasilkan berdasarkan penerapan pemikiran etis atas suatu profesi, dimana dapat berubah dan diubah seiring dengan perkembangan ilmu pengetahuan dan teknologi sehingga anggotanya tidak akan ketinggalan zaman. Oleh karena merupakan hasil pengaturan diri profesi yang bersangkutan dan merupakan perwujudan nilai moral yang hakiki yang tidak bisa dipaksakan dari luar maka hanya berlaku efektif apabila dijiwai oleh citacita dan nilai-nilai yang hidup dalam lingkungan profesi itu sendiri, sehingga merupakan suatu rumusan moral manusia yang mengemban profesi tersebut dan menjadi tolok ukur perbuatan anggota kelompok profesi serta merupakan upaya pencegahan berbuat yang tidak etis bagi anggotanya (Khie, 2002: 102).

Menurut Bertens, kode etik profesi merupakan norma yang ditetapkan dan diterima oleh kelompok profesi, yang mengarahkan atau memberi petunjuk kepada anggotanya bagaimana seharusnya berbuat dan sekaligus menjamin mutu moral profesi itu di mata masyarakat (Muhammad, 2006: 77). Dalam melaksanakan tugas jabatannya seorang Notaris harus berpegang teguh kepada kode etik jabatan, karena tanpa itu, harkat dan martabat profesionalisme akan hilang sama sekali (Lubis, 2008: 35). Kewajiban yang harus dilakukan oleh seorang sebagai pejabat umum selain diatur dalam UUJN juga diatur dalam ketentuan kode etik. Salah satu kewajiban yang terdapat dalam Ketentuan Pasal 3 KEN sebagaimana tersebut diatas adalah "menjalankan jabatan Notaris di kantornya kecuali, karena alasanalasan tertentu".

Ketentuan ini pada intinya mewajibkan notaris untuk menjalankan jabatan di kantornya, namun terdapat pengecualian terhadap kewajiban tersebut, yakni adanya "alasan-alasan tertentu". Sedangkan, terkait dengan apa-apa saja yang termasuk atau tergolong sebagai "alasan-alasan tertentu" sebagaimana dimaksud dalam ketentuan Pasal 3 angka 15 KEN tersebut, tidak diberikan penjelasan lebih lanjut baik dalam ketentuan KEN ataupun ketentuan lain. Pengertian kata "makna" itu sendiri dalam Kamus Besar Bahasa Indonesia (KBBI) adalah "memperhatikan setiap kata yang terdapat dalam tulisan, maksud pembicara atau penulis, atau pengertian yang diberikan kepada suatu bentuk kebahasaan". Sedangkan yang dimaksud dengan "memaknakan" dalam Kamus Besar Bahasa Indonesia (KBBI) adalah "menerangkan arti (maksud) suatu kata". Arti penting dalam mengetahui makna dari suatu kata atau kalimat adalah agar kita mengetahui secara jelas apa maksud atau apa pengertian dari kata atau kalimat tersebut.

Interpretasi terhadap teks hukum haruslah mengacu kepada cita hukum yakni keadilan, kepastian hukum, dan kehasilgunaan, nilai kemanusiaan yang fundamental, dan sistem hukum yang berlaku (Harianti, 2016, 240). Sebelum membahas tentang makna dari frasa "alasan-alasan tertentu" dalam hal ini terlebih dahulu perlu dibahas terkait dengan kalimat sebelumnya dalam ketentuan pasal tersebut yakni kalimat "menjalankan jabatan notaris di kantornya". Berdasarkan kalimat tersebut, dapat diartikan bahwa dalam pelaksanaan jabatannya seorang notaris diwajibkan untuk menjalankan jabatannya tersebut di kantornya, dalam hal ini penulis juga mengaitkan dengan ketentuan Kode Etik Notaris yang berlaku sebelum ada perubahan, yakni KEN berdasarkan Kongres Luar Biasa INI di Bandung tanggal 27 Januari 2005, yang mengatur hal yang sama dalam ketentuan Pasal 3 angka 14, yaitu "menjalankan jabatan terutama dalam pembuatan akta, pembacaan dan penandatanganan akta dilakukan di kantornya, kecuali karena alasan-alasan yang sah".

Berdasarkan ketentuan tersebut dalam hal ini dapat diartikan bahwa yang dimaksud dengan menjalankan jabatan 
adalah terkait dengan pembuatan, pembacaan dan penandatangannya, dan dapat diartikan bahwa semua perbuatan tersebut wajib dilaksanakan di kantor, namun dalam hal ini juga terdapat pengecualian yakni apabila terdapat alasan-alasan yang sah. Baik ketentuan KEN yang lama dan KEN perubahan dalam hal ini sama-sama mengatur terkait dengan kewajiban untuk menjalankan jabatan di kantornya, kecuali karena terdapat "alasan-alasan tertentu", hal ini menurut penulis secara argumentum a contrario atau penafsiran perlawanan, dapat diartikan bahwa notaris dapat saja atau diperbolehkan untuk menjalankan jabatan di luar kantonya asalkan dengan atau karena adanya "alasanalasan tertentu".

Maka dari itu sangat penting untuk mengetahui apa sebenarnya makna dari frasa "alasan-alasan tertentu" yang dimaksud dalam ketentuan KEN tersebut, karena tidak ada penjelasan lain terkait dengan hal tersebut. Arti kata "alasan" menurut Kamus Besar Bahasa Indonesia (KBBI) adalah "dasar, hakikat, atau dasar bukti (keterangan) yang dipakai untuk menguatkan pendapat (sangkalan). Sedangkan arti kata "tertentu" adalah sudah tentu, sudah pasti (jelas, terang), tetap, sudah dapat dipastikan atau ditentukan. Berdasarkan uraian diatas maka dapat kita ketahui bahwa makna frasa "alasan-alasan tertentu" dalam hal ini merujuk pada suatu dasar dalam pelaksanaan suatu perbuatan yang sudah ditentukan secara jelas dan pasti.

Pelaksanaan jabatan notaris seperti yang telah disebutkan diatas adalah terkait dengan pembuatan, pembacaan dan penandatanganan akta notaris itu sendiri. Dalam hal ini apabila dikaitkan dengan proses pembuatan akta itu sendiri, seperti telah diketahui bahwa tidak semua akta notaris dapat dibuat di kantor Notaris, karena akta Notaris mempunyai dua bentuk, yakni :

(a) akta partij atau akta pihak yaitu akta yang dibuat di hadapan notaris. Artinya, akta yang dibuat berdasar keterangan atau perbuatan pihak yang menghadap Notaris, dan keterangan atau perbuatan itu agar dikonstatir oleh Notaris untuk dibuatkan akta. Contohnya adalah Akta Jual Beli, Akta Tukar Menukar, Akta Kuasa.

(b) Akta relaas atau akta pejabat yaitu akta yang dibuat oleh Notaris sebagai pejabat umum yang memuat uraian secara otentik tentang semua peristiwa atau kejadian yang dilihat, dialami, dan disaksikan oleh Notaris sendiri. Contohnya adalah pembuatan Berita Acara Rapat Umum Pemegang Saham (RUPS) (Sumariningsih, 2001: 7).

Akta relaas atau akta pejabat dalam hal pembuatannya dilakukan di luar kantor, hal ini dikarenakan dalam pembuatan akta tersebut menuangkan apa yang dilihat, dialami dan disaksikan oleh notaris itu sendiri, dalam hal ini sebagai contoh adalah pembuatan akta dalam Rapat Umum Pemegang Saham selanjutnya disebut (RUPS), dimana dalam hal ini perseroan yang menjadi kliennya. Di dalam prakteknya hasil dari RUPS dituangkan dalam suatu akta otentik yang dibuat dihadapan Notaris, namun juga dapat dibuat dalam bentuk akta di bawah tangan dan kemudian akta tersebut dituangkan dalam bentuk akta otentik yang dikenal dengan Akta Pernyataan Keputusan Rapat.

Pembuatan Akta Pernyataan Keputusan Rapat yang dibuat dalam bentuk otentik, dalam hal ini Notaris turut hadir dan kemudian menuangkan hasil dari keputusan RUPS tersebut ke dalam suatu akta otentik, dan tentu hal ini dilakukan di luar kantor Notaris, karena RUPS ini umumya dilakukan di perusahaan yang mengadakan RUPS tersebut. Sehingga notaris dalam hal ini menyaksikan dan mendengar sendiri proses berjalannya RUPS, sehingga pada saat Notaris membuat akta, akta tersebut termasuk akta otentik. Selain akta risalah RUPS, akta lain yang pembuatannya dapat di lakukan di luar kantor adalah berita acara penarikan undian, akta protes tidak mau membayar atau akta-akta yang dihadiri oleh banyak pihak.

Alasan lain yang menurut penulis juga dapat dikategorikan sebagai "alasan-alasan tertentu" adalah terkait dengan klien atau 
pihak yang sedang dalam keadaan yang tidak memungkinkan untuk datang ke kantor, keadaan yang dimaksud dalam hal ini adalah keadaan sakit sehingga tidak memungkinkan meninggalkan rumah atau rumah sakit untuk menghadap notaris dalam hal pembuatan, pembacaan dan penandatanganan akta, maka penulis menganggap keadaan tersebut dapat dijadikan alasan bagi notaris untuk melakukan pembacaan dan penandatangan akta di luar kantor, dengan cara notaris yang bersangkutan datang ke tempat klien tersebut.

Untuk mencari atau menemukan maksud dan tujuan dari pembentukan suatu aturan, dapat mengaitkannya dengan ketentuan pasal-pasal lain atau ketentuan dari Undang-Undang lain yang mempunyai keterkaitan dengan hal tersebut yaitu Pasal 19 Ayat (3) UUJN yang menetapkan : "tidak berwenang secara berturut-turut dengan tetap menjalankan jabatan di luar tempat kedudukannya".

Penetapan notaris mempunyai tempat kedudukan di kota atau kabupaten, hal ini sebagaimana ditetapkan dalam Pasal 18 ayat (1) UUJN. Baik ketentuan Pasal 3 angka 15 KEN terkait kewajiban untuk pelaksanaan jabatan di kantornya, maupun Pasal 19 ayat (3) UUJN terkait ketidakberwenangan notaris untuk secara berturut turut dengan tetap menjalankan jabatan di luar tempat kedudukannya, hal ini tentu saling berkaitan, karena pelanggaran terhadap ketentuan Pasal 3 Angka 15 KEN, sebenarnya juga dikehendaki oleh aturan UUJN, melalui Pasal 19 ayat (3) tersebut.

Namun, pada kenyataanya ada kalanya notaris yang datang untuk menemui penghadap, bukan penghadap yang mendatangi kantor notaris (Merta, 2016). Hal ini tentu diperbolehkan dengan mengingat "alasanalasan tertentu" sebagai pengecualian. Penjelasan ketentuan Pasal 19 ayat (2) dalam UUJN, yang terdahulu sebelum ada perubahan yakni Undang-Undang Nomor 30 Tahun 2004 tentang Jabatan Notaris menyatakan bahwa akta notaris sedapat- dapatnya dilangsungkan di kantor notaris kecuali pembuatan akta-akta tertentu. Hal ini tentu sejalan dengan kewajiban notaris dalam KEN untuk menjalankan jabatan di kantornya, namun dalam hal ini dikecualikan untuk pembuatan akta-akta tertentu.

Alasan-alasan tertentu yang merupakan pengecualian terkait dengan pelaksanaan jabatan notaris di kantornya menjadi begitu penting, mengingat tanpa adanya kejelasan makna dari "alasan-alasan tertentu tersebut maka akan memunculkan celah bagi notaris untuk terus menerus menjalankan jabatan notaris di luar kantornya, yang kemudian juga akan berdampak pada pelanggaranpelanggaran lainnya terkait dengan kode etik maupun UUJN tersebut, dengan adanya kejelasan terkait dengan makna dari frasa "alasan-alasan tertentu" maka dalam hal ini notaris dapat mengetahui batasan-batasan yang jelas terkait dengan kewajibannya dan kewenangannya dalam menjalankan tugas jabatannya, sehingga senantiasa dapat sesuai dengan aturan UUJN maupun kode etik jabatannya tersebut.

Kepastian hukum menghendaki setiap peraturan yang ada, dibuat dan diundangkan harus pasti serta mengatur secara jelas dan logis. Dalam hal ini ketidakjelasan atau kekaburan makna "alasan-alasan tertentu" membuat notaris memberikan pengertian sendiri, dan tentu terhadap hal ini setiap notaris mempunyai penafsiran yang berbedabeda atau multi tafsir.

Kepastian hukum suatu peraturan sebagai hukum tertulis harus memenuhi syarat-syarat antara lain: (a) jelas dalam perumusannya (unambiguous); (b) konsisten dalam perumusannya (baik secara intern maupun ekstern). Konsisten secara intern mengandung makna bahwa dalam peraturan perundang-undangan yang sama harus terpelihara hubungan sietematik antara kaidah-kaidahnya, kebakuan susunan dan bahasa. Konsisten secara eketern, adalah adanya hubungan "harmonisasi" antara berbagai peraturan perundang-undangan; dan (c)penggunaan bahasa yang tepat dan 
mudah dimengerti.

Alasan-alasan tertentu tidak jelas sehingga menimbulkan penafsirkan yang berbeda-beda terkait dengan maknanya. Alasan-alasan tertentu yang dimaksudkan dalam ketentuan Pasal 3 angka 15 KEN tersebut, termasuk alasan atau keadaan yang memang diperbolehkan oleh ketentuan Undang-Undang, dan bukan alasan yang berasal dari notaris itu sendiri atau berdasarkan keadaan yang melanggar atau tidak diperbolehkan oleh ketentuan UUJN maupun KEN.

Maksud dari adanya ketentuan terkait dengan kewajiban pelaksanaan jabatan notaris di kantornya, adalah agar sedapat mungkin semua proses dari mulai pembuatan, pembacaan dan penandatangananya di lakukan di kantor, karena dengan pelaksanaan jabatan di luar kantor dapat memungkinkan terjadinya pelanggaran lain terkait ketentuan UUJN maupun kode etik, sehingga sedapatdapatnya harus dilakukan di kantor, kecuali memang terdapat "alasan-alasan tertentu" yang dapat dibenarkan dan tidak melanggar ketentuan UUJN maupun kode etik, yang dalam hal ini terkait keadaan-keadaan yang dibenarkan oleh UU, dan terkait dengan pembuatan akta relaas.

\section{Konsekuensi Pelanggaran Terhadap Ketentuan "Alasan-Alasan Tertentu" dalam Pasal 3 Angka 15 Kode Etik Notaris Terkait Kewajiban untuk Menjalankan Jabatan di Kantornya}

Pelanggaran menurut kamus hukum merupakan suatu jenis tindak pidana tetapi ancaman hukumnya lebih ringan daripada kejahatan, baik yang berupa pelanggaran jabatan atau pelanggaran undang-undang (Kamus Hukum, 2017).

Sedangkan menurut ketentuan Pasal 1 angka 9 KEN pelanggaran adalah perbuatan atau tindakan yang dilakukan oleh anggota perkumpulan yang bertentangan dengan kode etik dan/atau disiplin organisasi, dan orang lain yang memangku dan menjalankan jabatan notaris yang bertentangan dengan ketentuan kode etik. Terhadap suatu pelanggaran yang dilakukan oleh seseorang ataupun pejabat tentu menimbulkan suatu akibat hukum. Pelanggaran terkait ketentuan Pasal 3 angka 15 dengan akta otentik masih dipertanyakan apakah dapat mempengaruhi otentisitas dari akta notaris yang merupakan produk hukum yang dihendaki oleh para pihak sebagai suatu alat pembuktian yang memang memberikan perlindungan hukum bagi pihak yang membuatnya melalui jasa seorang notaris. Untuk mengetahui apakah pelanggaran terhadap ketentuan Pasal 3 angka 15 KEN dapat mempengaruhi otentisitas akta notaris karena tidak sesuai dengan syarat atau ketentuan terkait dengan otentisitas akta, sehingga berpengaruh terhadap otentisitas akta, maka terlebih dahulu kita harus mengetahui apa saja yang menjadi syarat otentisitas suatu akta otentik.

Pasal 1868 KUHPerdata merupakan sumber otentik akta notaris, dengan syaratsyarat sebagai berikut: (a) akta harus dibuat oleh (door) atau dihadapan (ten overstan) seorang pejabat umum; (b) akta harus dibuat dalam bentuk yang ditentukan oleh undang-undang; dan (c) pejabat umum, harus mempunyai wewenang yang dimaksudkan untuk membuat akta tersebut.

Akta yang dibuat oleh (door) dalam praktek disebut Akta Relaas atau Akta Berita Acara yang berisi berupa uraian yang dilihat dan disaksikan notaris sendiri atas permintaan para pihak, agar tindakan atau perbuatan para pihak yang dilakukan dituangkan ke dalam bentuk akta notaris. Akta yang dibuat dihadapan (ten overstan) notaris dalam praktek disebut Akta Pihak, yang berisi uraian atau keterangan, pernyataan para pihak yang diceritakan dihadapan notaris. Para pihak berkeinginan agar uraian atau keterangan tersebut dituangkan dalam bentuk akta notaris (Tombing, 1999: 51). Pembuatan akta notaris baik akta relaas maupun akta pihak, yang menjadi dasar utama atau inti dalam pembuatan akta notaris, yaitu harus ada keinginan atau kehendak (wilsvorming) dan permintaan dari para pihak, jika keinginan dan permintaan para 
pihak tidak ada, maka tidak akan membuat akta yang dimaksud.

Akta juga harus dibuat dalam bentuk yang ditentukan oleh undang-undang. Ketika kepada para notaris masih diberlakukan Peraturan Jabatan Notaris (PJN), masih diragukan apakah akta yang dibuat sesuai dengan undang-undang atau tidak. Setelah lahirnya UUJN keberadaan akta notaris mendapat pengukuhan karena bentuknya ditentukan oleh undang-undang, dalam hal ini ditentukan dalam Pasal 38 UUJN.

Pejabat umum oleh atau dihadapan siapa akta akta itu dibuat, harus mempunyai wewenang untuk membuat akta itu. Wewenang notaris dalam pembuatan akta otentik meliputi 4 (empat) hal. Notaris harus berwenang sepanjang yang menyangkut akta yang harus dibuat itu. Pertama, wewenang notaris dalam pembuatan akta otentik adalah sepanjang tidak dikecualikan kepada pihak atau pejabat lain, atau notaris juga berwenang membuatnya di samping dapat dibuat oleh pihak atau pejabat lain mengandung makna bahwa wewenang notaris dalam membuat akta otentik mempunyai wewenang yang umum, sedangkan pihak lainnya mempunyai wewenang terbatas. Kedua, notaris harus berwenang sepanjang mengenai orangorang untuk kepentingan siapa akta itu dibuat. Meskipun notaris dapat membuat akta untuk setiap orang, tetapi agar menjaga netralitas notaris dalam pembutan akta, ada batasan bahwa menurut ketentuan Pasal 52 UUJN notaris tidak diperkenankan untuk membuat akta untuk diri sendiri, isteri/ suami atau orang lain yang mempunyai hubungan kekeluargaan dengan notaris, baik karena perkawinan maupun hubungan darah dalam garis keturunan lurus ke bawah dan atau/ ke atas tanpa pembatasan derajat, serta dalam garis lurus ke samping sampai dengan derajat ketiga, serta menjadi pihak untuk diri sendiri, maupun dalam suatu kedudukan ataupun dengan perantaraan kuasa.

Ketiga, notaris harus berwenang sepanjang mengenai tempat, di mana akta itu dibuat. Notaris harus berwenang sepanjang mengenai tempat, di mana akta itu dibuat. Pasal 18 ayat (1) UUJN menentukan bahwa Notaris harus berkedudukan di daerah kabupaten atau kota. Setiap Notaris sesuai dengan keinginannya mempunyai tempat kedudukan dan berkantor di daerah kabupaten atau kota (Pasal 19 ayat (1) UUJN). Notaris mempunyai wilayah jabatan meliputi seluruh wilayah provinsi dari tempat kedudukannya (Pasal 19 ayat (2) UUJN). Notaris dalam menjalankan tugas jabatannya tidak hanya harus berada di tempat kedudukannya, karena notaris mempunyai wilayah jabatan seluruh provinsi, misalnya motaris yang berkedudukan di Kota Surabaya, maka dapat membuat akta di kabupaten atau kota lain dalam wilayah Provinsi Jawa Timur.

Keempat, notaris harus berwenang sepanjang mengenai waktu pembuat akta itu. Dalam menjalankan tugas jabatannya harus dalam keadaan fiktif, artinya tidak dalam keadaan cuti atau diberhentikan sementara waktu. Notaris yang sedang cuti, sakit, atau sementara berhalangan untuk menjalankan tugas jabatannya dapat menunjuk Notaris Pengganti (Pasal 1 angka 3 UUJN). Sedangkan tugas jabatan notaris dapat dilakukan oleh pejabat sementara untuk notaris yang kehilangan kewenangannya dengan alasan meninggal dunia, telah berakhir masa jabatannya, minta sendiri, tidak mampu secara rohani dan/atau jasmani untuk melaksanakan tugas jabatan sebagai notaris secara terus menerus lebih dari 3 (tiga) tahun, pindah wilayah jabatan, diberhentikan sementara, atau diberhentikan dengan tidak hormat.

Syarat otentisitas akta berdasarkan Pasal 1868, dikaitkan dengan pelanggaran kewajiban dalam Pasal 3 angka 15 KEN ada tiga. Pertama, akta tersebut dibuat oleh atau dihadapan seorang Pejabat Umum. Unsur ini harus terpenuhi, karena tentunya klien atau para pihak datang kepada notaris dengan kehendak atau keinginan untuk membuat suatu akta sebagai alat pembuktian bagi para pihak tersebut, baik dalam bentuk 
akta partij atau akta pihak atau akta relaas atau akta pejabat.

Kedua, akta itu harus dibuat dalam bentuk yang ditentukan oleh UndangUndang. Dalam hal ini apabila akta otentik yang dibuat oleh Notaris telah memenuhi ketentuan Pasal 38 UUJN mengenai bentuk akta, maka akta tersebut sudah dapat dikatakan sesuai dengan bentuk yang ditentukan oleh Undang-Undang. Ketiga, pejabat umum oleh atau dihadapan siapa akta itu dibuat, harus mempunyai wewenang untuk membuat akta itu. Dalam hal ini lebih difokuskan kepada unsur yang ketiga, yakni terkait dengan kewenangan notaris itu sendiri sebagai pejabat umum dalam membuat akta otentik, karena berdasarkan ketentuan Pasal 15 UUJN, notaris diberikan wewenang untuk membuat suatu akta otentik, namun dalam hal ini tentu terhadap kewenangan tersebut terdapat suatu batasan-batasan. Wewenang notaris dalam membuat akta otentik meliputi 4 hal, yaitu (1) notaris berwenang sepanjang yang menyangkut akta yang harus dibuat, (2) notaris harus berwenang sepanjang mengenai orang-orang untuk kepentingan siapa akta itu dibuat, (3) notaris harus berwenang sepanjang mengenai tempat, di mana akta itu dibuat dan (4) berwenang sepanjang mengenai waktu pembutan akta itu.

Berwenang sepanjang yang menyangkut akta yang harus dibuat, merupakan pembuatan akta otentik, tidak dikecualikan kepada pejabat lain atau pihak lain. Berwenang sepanjang mengenai orang-orang untuk kepentingan siapa akta itu dibuat, dimaksudkan untuk tidak diperkenankan membuat akta untuk dirinya sendiri, isteri/suami atau orang lain yang mempunyai hubungan kekeluargaan, baik karena perkawinan atau hubungan darah. Hal ini juga terkait dengan pihak yang akan dibuatkan suatu akta otentik, dalam hal ini juga harus memperhatikan apakah orang atau pihak tersebut berwenang dan mempunyai keterkaitan dengan objek yang akan dibuatkan akta otentiknya.

Berwenang sepanjang mengenai tempat, yaitu tempat akta itu dibuat. Kewenangan ini terkait dengan tempat akta dibuat sebagaimana dimaksud dalam ketentuan Pasal 18 ayat (1) UUJN yang menetapkan: (1) mempunyai tempat kedudukan di daerah kabupaten/ kota, dan (2) mempunyai wilayah jabatan meliputi seluruh wilayah provinsi dari tempat kedudukan. Berdasarkan hal tersebut, apabila dikaitkan dengan pelanggaran ketentuan Pasal 3 angka 15 terkait dengan kewajiban pelaksanaan jabatan di kantor, kecuali karena alasan-alasan yang tertentu, menurut penulis sebenarnya dalam hal ini tetap berwenang untuk membuat akta otentik, namun sepanjang pelaksanaanya tersebut masih berada di dalam wilayah jabatan, karena dalam ketentuan UUJN wilayah jabatan itu meliputi seluruh wilayah provinsi di tempat kedudukan, namun memang hal ini sepatutnya dilakukan hanya apabila ada "alasan-alasan tertentu" yang memang tidak memungkinkan untuk pelaksanaan jabatan di kantor, sehingga menyebabkan harus melaksanakan tugas jabatannya di luar kantor, dan selama hal tersebut tidak menjadi suatu keteraturan, atau dilakukan secara terus menerus atau berturut-turut di luar tempat kedudukan tersebut.

Keempat, berwenang sepanjang mengenai waktu pembutan akta itu berarti selama pembuatan akta otentik, notaris tersebut harus dalam keadaan aktif, artinya tidak sedang dalam masa cuti, sakit atau berhalangan hadir, diberhentikan sementara waktu atau belum mengucapkan sumpah jabatan. Dalam keadaan cuti, sakit atau berhalangan maka notaris yang bersangkutan akan menunjuk seorang pengganti. Dalam hal ini berarti selama yang membuat akta tidak dalam keadaan tersebut diatas, maka tersebut mempunyai kewenang untuk membuat akta otentik, baik akta partij maupun akta relaas.

Ketentuan-ketentuan mengenai syarat otentisitas akta tersebut diatas mempunyai sifat kumulatif atau bersangkutan satu dengan yang lainnya, sehingga dalam hal ini kesemuanya itu harus terpenuhi agar suatu 
akta dapat dikatakan otentik, jadi dalam hal ini selama semua ketentuan mengenai syarat otentisitas akta telah terpenuhi oleh notaris dalam pelaksanaan jabatannya, maka tidak akan berpengaruh terhadap otentisitas akta notaris tersebut. Sehingga dalam hal ini penulis dapat menyimpulkan, apabila notaris melakukan pelanggaran terhadap ketentuan Pasal 3 angka 15 dalam pembuatan akta otentik, namun dalam pembuatannya tidak melanggar salah satu ataupun beberapa bahkan semua syarat otentisitas akta, maka akta tersebut tetap merupakan suatu akta otentik.

Dalam hal ini otentisitas akta notaris apabila dikaitkan dengan ketentuan terkait dengan tempat kedudukan dan wilayah jabatan notaris apabila terjadi pelanggaran terkait dengan ketentuan Pasal 3 angka 15 KEN, yakni terkait menjalankan jabatan di luar kantornya tanpa disertai "alasan-alasan tertentu", penulis membaginya kedalam 3 jenis. Pertama, pelaksanaan jabatan notaris yang dilakukan di luar kantor notaris tetapi masih berada dalam tempat kedudukan notaris, tempat kedudukan notaris meliputi daerah kabupaten atau kota, untuk itu apabila notaris melaksanakan tugas jabatan di luar kantornya artinya di luar tempat kedudukannya, maka dalam hal ini pelaksanaan jabatan notaris yang meliputi pembuatan, pembacaan dan penandatanganan aktanya dinggap sah, dan aktanya merupakan akta otentik, selama semua persyaratan keotentikan akta sebagaimana telah ditetapkan oleh UUJN telah terpenuhi. Namun apabila Notaris yang melakukan pelanggaran terhadap ketentuan Pasal 3 angka 15 KEN menyebabkan salah satu unsur, beberapa atau bahkan semua syarat otentisitas akta tidak terpenuhi, ataupun melanggar syarat atau ketentuan UUJN terkait dengan akta otentik, maka akta tersebut akan terdegradasi, sehingga hanya mempunyai kekuatan pembuktian sebagai akta di bawah tangan.

Kedua, pelaksanaan jabatan Notaris yang dilakukan di luar kantor tanpa alasan-alasan tertentu yang masih dalam wilayah jabatan notaris yang bersangkutan, dalam hal ini diperbolehkan karena seperti diketahui bahwa notaris mempunyai wilayah jabatan meliputi seluruh provinsi di tempat kedudukannya, namun dalam hal ini tentu harus tetap memperhatikan ketentuan dalam Pasal 19 ayat (3) UUJN, yang menetapkan bahwa notaris tidak berwenang secara berturut-turut dengan tetap menjalankan jabatan di luar tempat kedudukannya, yang berarti bahwa kegiatan pelaksanaan jabatannya lebih sering dilakukan di luar kantor daripada di kantor notaris. Untuk itu dalam hal ini terkait dengan pelaksanaan jabatan notaris yang meliputi pembuatan, pembacaan dan penandatanganan akta dalam hal ini dianggap sah dan aktanya merupakan akta otentik selama tidak melanggar ketentuan terkait dengan otentisitas akta yang diatur dalam UUJN. Namun apabila pelaksanaan jabatan notaris di luar tempat kedudukan dilakukan secara berturut-turut, maka Notaris dalam hal ini menjadi tidak berwenang, hal ini sebagaimana ketentuan Pasal 19 ayat (3). Dalam hal ini larangan untuk terus menerus atau secara berturut-turut menjalankan jabatan di luar kantor bertujuan untuk mencegah agar tidak terjadi persaingan tidak sehat antar sesama Notaris di tempat kedudukan tersebut.

Ketiga, pelaksanaan jabatan notaris yang dilakukan di luar kantor tanpa alasan-alasan tertentu dan hal ini dilakukan di luar wilayah jabatan notaris adalah tidak sah, karena notaris dalam hal ini tidak mempunyai kewenangan untuk melaksanakan jabatannya di luar wilayah jabatannya atau di luar wilayah provinsi di tempat kedudukannya, karena notaris hanya mempunyai kewenangan membuat akta meliputi seluruh wilayah provinsi dari tempat kedudukannya, sehingga akta yang dibuat akan kehilangan otentisitasnya dan akan terdegradasi menjadi akta di bawah tangan, karena dalam hal ini telah melanggar ketentuan mengenai kewenangan notaris terkait tempat akta dibuat atau tempat pembutan akta, sehingga notaris tidak memiliki kewenangan dan karena melanggar 
perintah Undang-Undang.

Akta notaris sebagai akta otentik mempunyai kekuatan nilai pembuktian, yaitu lahiriah (Uitwendige Bewijskracht), formal (Formele Bewijskracht), dan materil (Materiele Bewijskracht). Secara lahiriah, akta notaris itu sendiri memiliki kemampuan untuk membuktikan keabsahannya sebagai akta otentik (acta publica probant sese ipsa). Kemampuan lahiriah akta notaris ditentukan dalam Pasal 38, 42 dan 43 UUJN.

Secara formal, untuk membuktikan kebenaran dan kepastian tentang hari, tanggal, bulan, tahun, pukul (waktu) menghadap, dan para pihak yang menghadap, paraf dan tanda tangan para pihak/penghadap, saksi dan notaris, serta membuktikan apa yang dilihat, disaksikan, didengar oleh notaris (pada akta pejabat/berita acara), dan mencatatkan keterangan atau pernyataan para pihak/penghadap (pada akta pihak). Hal ini sebagaimana kewenangan Notaris berdasarkan Pasal 15 ayat (1) UUJN.

Secara materiil, merupakan kepastian tentang materi suatu akta, bahwa apa yang tersebut dalam akta merupakan pembuktian yang sah terhadap pihak-pihak yang membuat akta atau mereka yang mendapat hak dan berlaku untuk umum, kecuali ada pembuktian sebaliknya (tegenbewijs). Keterangan atau pernyataan yang dituangkan/dimuat dalam akta pejabat (atau berita acara), atau keterangan atau para pihak yang diberikan/ disampaikan dihadapan notaris (akta pihak) dan para pihak harus dinilai benar berkata yang kemudian dituangkan/dimuat dalam akta berlaku sebagai yang benar atau setiap orang yang datang menghadap notaris yang kemudian/keterangannya dituangkan/dimuat dalam akta harus dinilai telah benar berkata (Notodisoerjo, 1982: 55).

Akta notaris yang tidak memenuhi kekuatan pembuktian lahiriah, formal dan materiil serta tidak memenuhi ketentuan yang telah ditetapkan oleh undang-undang akan mengandung cacat yuridis, sehingga akan menimbulkan konsekuensi yaitu kehilangan otentisitasnya, sehingga menjadi terdegradasi sebagai akta yang hanya mempunyai kekuatan pembuktian di bawah tangan saja. Hal yang juga penting terkait otentisitas akta adalah terkait dengan pembacaan dan penandatanganan akta. Pembacaan akta dilakukan berdasarkan ketentuan Pasal 16 ayat (1) huruf $m$ UUJN yang menyatakan "membacakan akta di hadapan penghadap dengan dihadiri oleh paling sedikit 2 (dua) orang saksi atau 4 (empat) orang saksi khusus untuk pembuatan akta wasiat di bawah tangan, dan ditandatangani pada saat itu juga oleh penghadap, saksi, dan notaris".

Terkait dengan pembacaan ini, tidak wajib untuk dilakukan jika, para penghadap menghendaki agar akta tidak dibacakan, karena penghadap telah membaca sendiri, mengetahui dan memahami isinya, dengan ketentuan bahwa hal ini harus dinyatkan dalam penutup akta, pada setiap halaman minuta akta, dan diparaf oleh penghadap, saksi, dan Notaris. Namun ketidak wajiban pembacaan akta tersebut dikecualikan terhadap pembacaan kepala akta, komparisi, penjelasan pokok akta secara singkat, dan jelas, serta penutup akta (Pasal 16 ayat 8 UUJN). Dan dalam hal ini apabila pelaksanaan jabatan Notaris di luar kantor, dalam hal pembacaanya tidak memenuhi syarat terkait pembacaan akta tersebut diatas, yakni tidak memenuhi ketentuan tersebut diatas, maka berdasarkan ketentuan Pasal 16 ayat (9) akta Notaris yang bersangkutan hanya mempunyai kekuatan pembuktian sebagai akta di bawah tangan, terkecuali pembuatan akta wasiat.

Pembacaan dan penandatanganan dalam hal ini merupakan suatu kesatuan, dan merupakan rangkaian kegiatan yang berturut-turut, karena setelah dilakukan pembacaan akta oleh notaris, akan dilakukan penandatangan akta. Hal tersebut diatur dalam ketentuan Pasal 44 UUJN yang menyatakan setelah akta dibacakan akan ditandatangani oleh setiap penghadap, saksi, dan notaris, kecuali apabila ada penghadap yang tidak dapat membubuhkan tanda tangan dengan menyebutkan alasannya. Alasan tersebut 
harus dinyatakan dan dituliskan secara tegas pada bagian akhir akta.

Pelanggaran terhadap ketentuan tersebut akan mengakibatkan suatu akta hanya mempunyai kekuatan pembuktian sebagai akta di bawah tangan dan dapat menjadi alasan bagi pihak yang menderita kerugian untuk menuntut penggantian biaya, ganti rugi, dan bunga kepada notaris. Dalam hal ini pembacaan dan penandatanganan akta juga berkaitan dengan saksi yang ikut hadir dan menyaksikan segala proses sampai pada akta selesai ditandatangani. Hal ini sebagaimana dimaksud dalam ketentuan Pasal 40 UUJN. Saksi akta notaris merupakan para saksi yang ikut serta di dalam pembuatan terjadinya akta (instrumen), maka dari itulah disebut saksi instrumentair (Instrumentaire Getuigen). Mereka dengan jalan membubuhkan tanda tangan mereka, memberikan kesaksian tentang kebenaran adanya dilakukan dan dipenuhinya formalitas-formalitas yang diharuskan oleh Pasal 38 UUJN, yang disebutkan dalam akta tersebut. Biasanya, yang menjadi saksi instrumentair ini adalah karyawan notaris itu sendiri. Dan pelanggaran terhadap ketentuan tersebut diatas juga dapat menyebabkan akta tersebut kehilangan otentisitasnya, dan terdegradasi menjadi hanya mempunyai kekuatan pembuktian di bawah tangan.

Kedudukan notaris sebagai pejabat umum merupakan suatu jabatan terhormat yang diberikan oleh negara secara atributif melalui undang-undang kepada seseorang yang dipercayainya. Sebagai pejabat umum, notaris diangkat oleh Menteri Hukum dan HAM, hal tersebut berdasarkan Pasal 2 UUJN. Dengan diangkatnya seorang Notaris maka Notaris dapat menjalankan tugasnya dengan bebas, tanpa dipengaruhi badan eksekutif dan badan lainnya dan dapat bertindak netral dan independen (Sulihandari dan Rifiani, 2013:4). Seorang notaris mempunyai kewenangan untuk membuat akta otentik yang diatur dalam ketentuan Pasal 15 UUJN, dan dalam hal ini tentu dalam pelaksanaan tugasnya seorang Notaris haruslah sesuai dengan kewenangan yang telah diberikan, dan tidak boleh melebihi batas kewenangan yang telah diberikan, apabila Notaris melakukan hal-hal di luar kewenangan yang telah diberikan kepadanya maka dalam hal ini termasuk sebagai perbuatan di luar wewenang Notaris. Untuk itu, apabila perbuatan di luar wewenang tersebut menimbulkan permasalahan bagi para pihak, yang menimbulkan kerugian secara materiil maupun immateril, maka pihak yang merasa dirugikan tersebut dapat mengajukan gugatan ke pengadilan (Adjie, 2011: 14). Sebagai contoh, apabila notaris dengan sengaja melakukan penyimpangan terhadap akta yang dibuatnya sehingga menimbulkan perkara pidana maka notaris harus mempertanggungjawabkannya (Pramarta, 2018). Selain itu perbuatan di luar wewenang yang dilakukan oleh notaris juga dapat berakibat terhadap otentisitas akta, yakni terdegradasi menjadi hanya mempunyai kekuatan pembuktian sebagai akta di bawah tangan.

Berdasarkan beberapa uraian tersebut diatas dalam hal ini dapat diketahui, bahwa berdasarkan teori kewenangan, notaris mempunyai kewenangan atribusi, dimana notaris diberikan kewenangan langsung oleh undang-undang untuk membuat akta otentik, dimana hal ini mencakup pembuatan, pembacaan dan penandatanganan akta, dan terkait dengan pelaksanaan tugas jabatannya di luar kantor apabila tidak disertai dengan "alasan-alasan tertentu", namun selama tempat pembuatan akta masih berada dalam wilayah jabatan notaris yang meliputi seluruh provinsi di tempat kedudukannya dan tidak dilakukan secara terus menerus atau berturut-turut di luar tempat kedudukan, maka notaris tetap mempunyai kewenangan untuk membuat akta notaris, sekalipun pembuatan, pembacaan dan penandatangannya dilakukan di luar kantor, namun dengan tetap memperhatikan bahwa hal ini tidak boleh dijadikan kesempatan bagi Notaris untuk terus menerus melakukan 
penandatangan akta di luar kantor notaris, hal ini mengingat ketentuan Pasal 19 ayat (3) UUJN yang menyebutkan bahwa notaris tidak berwenang secara berturutturut dengan tetap menjalankan jabatan di luar tempat kedudukannya. Apabila pelanggaran ketentuan Pasal 3 angka 15

\section{SIMPULAN}

1. Makna dari "alasan-alasan tertentu" dalam ketentuan Pasal 3 angka 15 KEN adalah alasan-alasan atau keadaankeadaan yang diperbolehkan dan tidak melanggar ketentuan UUJN maupun melanggar ketentuan KEN. Tergolong ke dalam "alasan-alasan tertentu" adalah terkait dengan pembuatan akta relaas atau akta pejabat yang tidak dimungkinkan dilaksanakan di kantor notaris, seperti akta Berita Acara Rapat Umum Pemegang Saham, atau pada saat klien atau pihak yang sedang dalam keadaan sakit, tidak memungkinkan untuk meninggalkan rumah atau rumah sakit untuk menghadap notaris, sehingga mengharuskan notaris untuk mendatangi kliennya tersebut dalam hal pembuatan akta. Perlu dijelaskan secara pasti dalam ketentuan KEN sesuatu hal yang tergolong dalam "alasan-alasan tertentu", sehingga akan tercapai suatu kepastian terkait dengan makna "alasanalasan tertentu" yang dimaksud dalam

\section{DAFTAR RUJUKAN}

Adjie, Habib. 2011. Kebatalan dan Pembatalan Akta Notaris. Bandung: Refika Aditama.

Harianti, Aries. 2016. Hukum Ketenagakerjaan Makna Kesusilaan dalam Perjanjian Kerja. Yogyakarta: Laksbang Pressindo.

Kitab Undang-Undang Hukum Perdata

Khie, Tong Tan. 2002. Buku I, Studi Notariat (Beberapa Mata Pelajaran dan Serba Serbi Praktek). Jakarta: Ictiar Baru Van Hoeve.

Kode Etik , Kongres Luar Biasa Ikatan Indonesia, Bandung 28 Januari 2005.
KEN ternyata tidak memenuhi salah satu unsur atau beberapa syarat otentisitas akta otentik, melanggar ketentuan UUJN terkait otentisitas akta, maka akta tersebut menjadi kehilangan otentisitasnya, dan hanya mempunyai kekuatan pembuktian sebagai akta di bawah tangan.

ketentuan KEN tersebut.

2. Pelanggaran terhadap ketentuan Pasal 3 Angka $15 \mathrm{KEN}$ tidak serta merta mempengaruhi otentisitas akta otentik, karena dalam hal menurut ketentuan UUJN, notaris masih berwenang untuk membuat akta di luar kantor (di luar tempat kedudukan, asalkan masih dalam wilayah jabatannya), namun apabila pelanggaran terhadap ketentuan Pasal 3 angka $15 \mathrm{KEN}$, ternyata menyebabkan tidak terpenuhinya salah satu atau beberapa syarat otentisitas akta, maka hal ini menyebabkan akta tersebut kehilangan otentisitasnya dan terdegradasi sehingga hanya mempunyai kekuatan pembuktian sebagai akta di bawah tangan, dan hal ini tentu dengan tetap memperhatikan bahwa pelaksanaan jabatan di luar kantor tidak dilakukan secara berturutturut ataupun di luar wilayah jabatan, karena tidak mempunyai kewenangan terkait dengan hal tersebut.

Lubis, K Suhrawardi. 2008. Etika Profesi Hukum. Jakarta: Sinar Grafika.

Merta, M. Novansyah. 2016. Jurnal Magister Kenotariatan Fakultas Hukum Universitas Sriwijaya, Kajian Tentang Keabsahan Akta Notaris yang Penandatanganannya Tidak Di Kantor.

Muhammad, Abdulkadir. 2006. Etika Profesi Hukum, Bandung: PT. Citra Aditya Bakti.

Notodisoerjo, Soegondo R. 1982. Hukum Notariat di Indonesia (Suatu 
Penjelasan). Jakarta: Rajawali.

Pengurus Pusat Ikatan Notaris Indonesia. 2008. Jati Diri Notaris Indonesia, Dulu, Sekarang Dan Di Masa Datang. Jakarata: PT. Gramedia Pustaka.

Perubahan Kode Etik. Kongres Luar Biasa Ikatan Indonesia, Banten 29 Mei 2015.

Pramarta, Billy Adhi, dkk. 2018. Pertanggungjawaban Pidana Notaris dan Para Pihak yang Memalsukan Surat Keterangan Obyek Pewaris. Jurnal Ilmiah Pendidikan Pancasila dan Kewarganegaraan. (Online), Volume 3, Nomor 1, Halaman 22-29, Juni 2018 (http://journal2.um.ac.id/ index.php/jppk/article/view/6023/3091, diakses pada 20 April 2019)

Sulihandar, Hartanti dan Rifiani, Nisya. 2013. Prinsip-Prinsip Dasar Profesi Notaris. Jakarta: Dunia Cerdas.

Sumarningsih, Eka F. 2001. Peraturan Jabatan Notaris. Diktat Kuliah Program Studi Notariat, Semarang: Fakultas
Hukum Universitas Dipenogoro.

Tombing, Lumban G.H.S. 1999. Peraturan Jabatan. Jakarta: Erlangga.

Republik Indonesia. 2004. Undang-Undang Nomor 30 Tahun 2004 tentang Jabatan. Lembaran Negara No. 117, Tahun 2004.

Republik Indonesia 2014. Undang-Undang Nomor 2 Tahun 2004 tentang Perubahan Atas Undang-Undang Nomor 30 Tahun 2004 tentang Jabatan. Lembaran Negara No. 3, Tahun 2014.

Yoga, I Gusti Kade Prabawa Maha, dkk. 2018. Kewenangan Notaris dalam Pembuatan Surat Keterangan Waris Untuk Warga Negara Indonesia. Jurnal Ilmiah Pendidikan Pancasila dan Kewarganegaraan. (Online), Volume 3, Nomor 2, Halaman 132143, Desember 2018 (http://journal2. um.ac.id/index.php/jppk/article/ view/7817/3746, diakses pada 20 Maret 2019) 